\title{
Degradation Characteristics of Aniline with Ozonation and Subsequent Treatment Analysis
}

\author{
Zhaoqian Jing, Shiwei Cao, Ting Yu, and Jing $\mathrm{Hu}$ \\ College of Civil Engineering, Nanjing Forestry University, Nanjing 210037, China \\ Correspondence should be addressed to Zhaoqian Jing; zqjing@yahoo.com
}

Received 21 May 2015; Revised 16 July 2015; Accepted 22 July 2015

Academic Editor: Huu H. Ngo

Copyright ( 2015 Zhaoqian Jing et al. This is an open access article distributed under the Creative Commons Attribution License, which permits unrestricted use, distribution, and reproduction in any medium, provided the original work is properly cited.

\begin{abstract}
Owing to the toxicity and low biodegradability of aniline in water, its removal usually needs high cost processes such as adsorption and advanced oxidation. The degradation characteristics of aniline during ozonation were studied. The influence of operation parameters such as contact time, initial concentration, ozone dosage, temperature, and $\mathrm{pH}$ was also investigated. With ozone dosage of $22 \mathrm{mg} / \mathrm{L}$, neutral $\mathrm{pH}$, and room temperature, the ozonation removed aniline efficiently. After two hours' ozonation, aniline removal reached $93.57 \%$, and the corresponding COD removal was $31.03 \%$, which indicated most of aniline was transformed into intermediates. At alkaline conditions, the aniline was more susceptible to being removed by ozonation owing to more hydroxyl radicals' production. The results of GC-MS indicated many intermediates appeared during the process of ozonation such as butane diacid, oxalic acid, and formic acid. The intermediates produced during ozonation were more biodegradable than aniline; thus the ozonation of such organic compounds as aniline could be integrated with biological processes for further removal.
\end{abstract}

\section{Introduction}

Aniline, the most typical compound in aromatic amines, is a kind of colorless oily liquid with sweet smelling. Aniline is an important raw material and intermediate for organic chemistry [1], which is widely used in some industries such as pesticide [2], medicine [3], oil paint, dyes [4], plastic [5], military, and defense products [6]. Aniline is detrimental to both environment and human's health. It enters the human body by skin, respiratory tract, and digestion system, resulting in carcinogenic, teratogenic, and mutagenic effects on human being [7]. When aniline is discharged into water bodies, it usually disturbs water environment and brings about serious water pollution and even the death of aquatic animals and plants [8]. Because aniline is widely used in many industries, aniline exists in different kinds of industrial wastewater and municipal wastewater. Due to the high toxicity and accumulation of aniline in the environment, more and more rigorous limits on the letting amount of aniline have been established in many countries and districts [9]. When aniline in wastewater exceeds a certain concentration, it will cause detrimental effects to microorganisms in the treatment processes. Consequently, it must be removed or transformed into biodegradable substances before biological treatment processes.

The regular treatment methods for aniline removal include physical treatment, chemical treatment, and biological treatment [10]. In the physical methods, adsorption with activated carbon and macroporous resin is widely used [11, 12]. There are also other methods such as organic solvent extraction and membrane separation. However, the cost of these methods is usually high. In the chemical methods, advanced oxidation processes such as catalytic oxidation [13], ozonation [14], electrochemical degradation method [15], and ultrasonic degradation [16] have been proven effective in aniline removal. Nevertheless, these methods also have the problem of high cost and complicated maintenance [17]. Moreover, most of these advanced oxidation methods can only transform aniline into many intermediates, which also cause adverse effect to water environment. There are also some researches using biological processes as activated sludge system [18], biological contact oxidation, and anaerobic treatment [19]. However, direct biological treatment usually needs long time cultivation for the microorganisms 
to accommodate to the wastewater with high level of harmful aniline [20]. It is also sensitive and fragile to shock load, resulting in unstable performances.

In this study, aniline was disposed by ozonation. Aniline removal and the corresponding COD (Chemical Oxygen Demand) removal were determined during the ozonation. The effects of contact time, initial aniline concentration, ozone dosage, temperature, and $\mathrm{pH}$ on aniline and COD removal were studied. The possible degradation routes and intermediates during ozonation were also investigated. The appropriate process with the integrated system of ozonation and biological treatment was suggested.

\section{Material and Methods}

2.1. Reactor. $1 \mathrm{~L}$ of aniline solution with certain initial concentration was put into a graduated glass cylinder. An aerator was connected with an ozone generator and then put at the bottom of the cylinder. The influence of contact time, initial aniline concentration, ozone dosage, temperature, and $\mathrm{pH}$ on aniline degradation was investigated. Ozone was produced with an ozone generator (CF-G-3, ozone generation capacity: $2.5 \mathrm{~g} / \mathrm{h}$, Qingdao Guolin Industry Co., Ltd., China) with dry air. Ozone dosage was controlled in the range of $10-45 \mathrm{mg} / \mathrm{L}$ by calculation from the ozone gas composition changes before and after the ozonation.

2.2. Water Matrix. The aniline solution was made with distilled water with certain dosage of aniline. The $\mathrm{pH}$ of the solutions was adjusted with $1 \mathrm{~mol} / \mathrm{L}$ solutions of $\mathrm{HCl}$ or $\mathrm{NaOH}$. Aniline and the corresponding COD concentration during ozonation were measured.

2.3. Analytical Methods. The samples were taken from the cylinder reactor at certain time. The concentrations of aniline and COD were analyzed according to the standard methods [21]. The possible products of ozonation were measured with a GC-MS (Trace DSQ, Thermo Fisher Scientific, Waltham, USA). It used a DB-5S capillary column $(30 \mathrm{~m} \times 0.25 \mathrm{~mm}$ $\times 0.25 \mu \mathrm{m})$ with helium as the carrier gas at a flow rate of $1 \mathrm{~mL} / \mathrm{min}$. The GC column oven temperature was held at $50^{\circ} \mathrm{C}$ for $3 \mathrm{~min}$ and then programmed heating from 50 to $280^{\circ} \mathrm{C}$ at a rate of $10^{\circ} \mathrm{C} / \mathrm{min}$, with a final hold time of $5 \mathrm{~min}$. The sampling temperature was controlled at $260^{\circ} \mathrm{C}$. The injection was conducted in the splitless mode with injection volume of $1 \mu \mathrm{L}$. The mass spectrometer was operated in the electron ionization mode $(70 \mathrm{ev})$ and a source temperature of $250^{\circ} \mathrm{C}$. Before GC-MS, the water samples were filtrated with $0.45 \mu \mathrm{m}$ polyethersulfone membrane and then extracted with $\mathrm{n}$-hexane at a dosage of $5 \mathrm{~mL}$ for $25 \mathrm{~mL}$ filtrate. The extracted solution was used for GC-MS analysis.

\section{Results and Discussion}

3.1. The Effect of Contact Time on Aniline Ozonation. The effect of contact time on aniline ozonation was studied at $\mathrm{pH}$ 7 and $20^{\circ} \mathrm{C}$ with ozone dosage of $22 \mathrm{mg} / \mathrm{L}$. Figure 1 showed

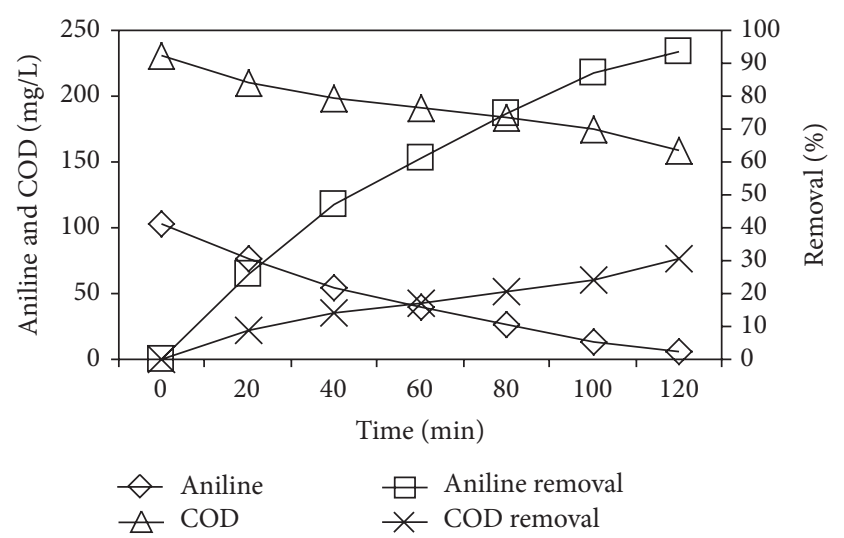

Figure 1: Effect of contact time on aniline removal. pH: 7.0; temperature: $20^{\circ} \mathrm{C}$; ozone dosage: $22 \mathrm{mg} / \mathrm{L}$.

the variation of aniline and COD removal with time extension during the ozonation.

During the ozonation, the concentration of aniline decreased with contact time extension. In two hours' ozonation, aniline decreased from $103.81 \mathrm{mg} / \mathrm{L}$ to $6.68 \mathrm{mg} / \mathrm{L}$ with removal rate of $93.57 \%$, which indicated the excellent degradation effect of ozonation on aniline.

Although the ozonation could remove most of the aniline during the ozonation, the COD removal rate only attained $31.03 \%$ in two hours, which indicated most of the aniline was transformed into intermediate products. During the ozonation, aniline solution showed a series of colors as pink, purplish red, reddish orange, orange, yellow, reddish brown, and light yellow. These complicated colors during aniline's ozonation implied that many intermediate products were produced from aniline's transformation. According to the results of GC-MS, the main intermediates during ozonation of aniline were benzoquinone. There were also nitrobenzene and nitroaniline. These products were related with orange, yellow, and brown colors according to their concentration and existing state during the ozonation. Because the azyl on the benzene ring was susceptible to being attacked by ozone and hydroxyl radicals, there were also some intermediates such as benzenediamine, which showed the color of pink and purplish red. The final solution color of light yellow indicated that most of these intermediates were further degraded during ozonation. However, these intermediates could not be completely mineralized by ozonation due to the formation of partial oxidation products relatively unreactive towards ozone [22], which still represented much COD in the solution. If the residual COD was to be removed, other oxidation methods or biological processes would be needed.

3.2. The Effect of Initial Aniline Concentration on Ozonation. At $20^{\circ} \mathrm{C}$ and ozone dosage of $22 \mathrm{mg} / \mathrm{L}$, the influence of initial aniline concentration was showed in Figure 2. With the initial aniline concentration rise, both aniline and COD removal decreased. At initial aniline concentration of $50 \mathrm{mg} / \mathrm{L}$, aniline and COD removal, respectively, reached $96.59 \%$ and $50.00 \%$ after two hours' ozonation. When the initial aniline 


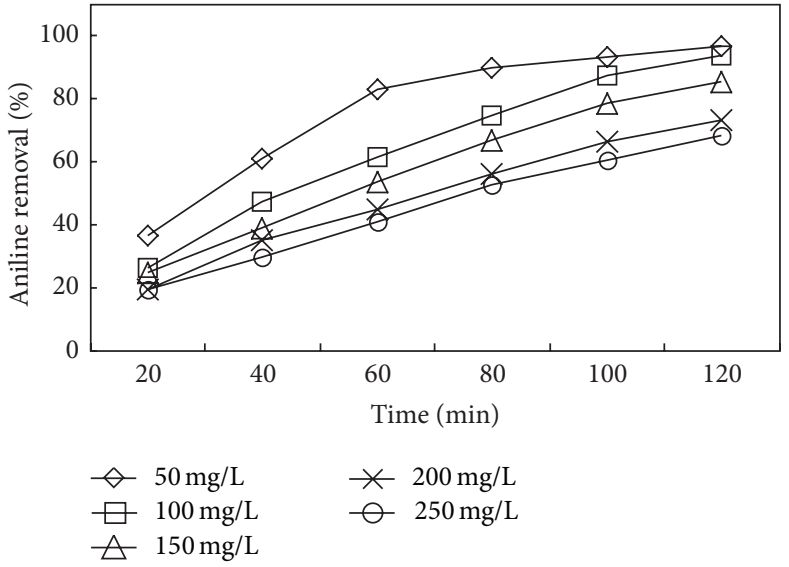

(a)

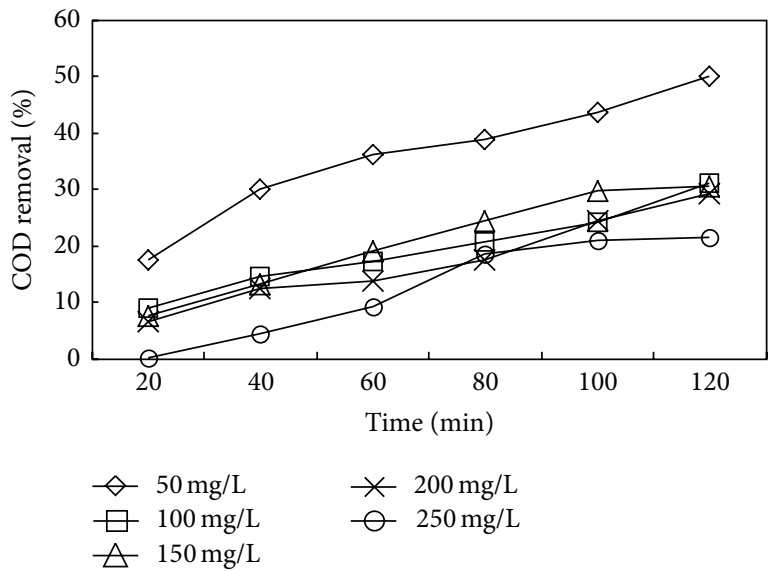

(b)

FIgURE 2: Effect of initial aniline concentration on aniline (a) and COD (b) removal. pH: 7.0; temperature: $20^{\circ} \mathrm{C}$; ozone dosage: $22 \mathrm{mg} / \mathrm{L}$.

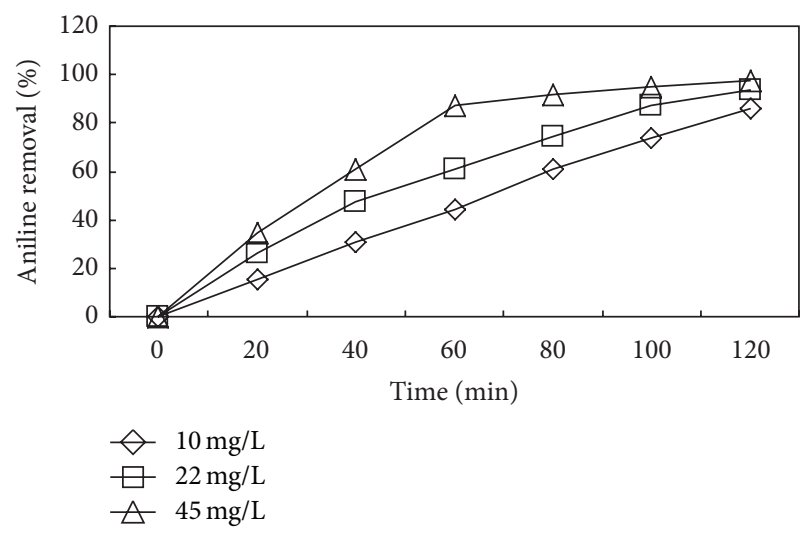

(a)

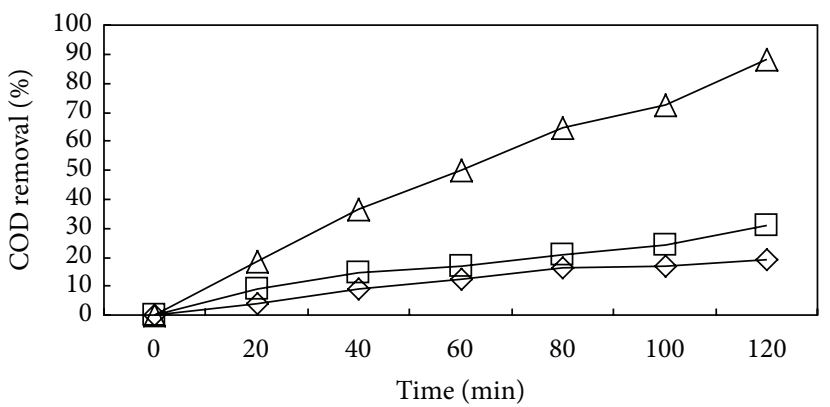

$$
\begin{aligned}
& \diamond 10 \mathrm{mg} / \mathrm{L} \\
& \square \quad 22 \mathrm{mg} / \mathrm{L} \\
& \triangle 45 \mathrm{mg} / \mathrm{L}
\end{aligned}
$$

(b)

FIGURE 3: Effect of ozone dosage on aniline (a) and COD (b) removal. pH: 7.0; temperature: $20^{\circ} \mathrm{C}$; initial aniline concentration: $100 \mathrm{mg} / \mathrm{L}$.

concentration was increased to $250 \mathrm{mg} / \mathrm{L}$, the corresponding removal rates of aniline and COD were only $68.28 \%$ and $21.44 \%$, respectively.

When the initial aniline concentration was high, the ozonation was overloaded, and the organic compounds could not be transformed into intermediates completely. At the lowest initial aniline concentration, aniline was almost transformed into intermediates, and about half of the intermediates were further degraded into carbon dioxide and water. When most of the aniline was transformed into intermediates, the intermediates could be easily removed by further processes such as biological treatment [23].

3.3. The Effect of Ozone Dosage on Aniline Ozonation. At $20^{\circ} \mathrm{C}, \mathrm{pH} 7$, the effect of ozone dosage on aniline ozonation was studied with ozone dosage ranging from $10 \mathrm{mg} / \mathrm{L}$ to $45 \mathrm{mg} / \mathrm{L}$ (Figure 3). The increase of ozone dosage accelerated aniline and COD removal obviously. At ozone dosage of $10 \mathrm{mg} / \mathrm{L}$, aniline removal was $85.94 \%$ after two hours' ozonation. When the dosage was increased to $45 \mathrm{mg} / \mathrm{L}, 97.19 \%$ of aniline was eliminated in two hours, and the removal at $80 \mathrm{~min}$ reached $91.94 \%$. These results indicated ozone dosage rise accelerated the aniline's degradation. Most of aniline could be removed under these three levels of ozone dosage from $10 \mathrm{mg} / \mathrm{L}$ to $45 \mathrm{mg} / \mathrm{L}$. COD removal at these three levels of ozone dosage after two hours' ozonation was $19.31 \%, 31.03 \%$, and $88.28 \%$, respectively. Ozone dosage of $45 \mathrm{mg} / \mathrm{L}$ got the highest COD removal, which indicated most of the intermediates could be further degraded into carbon dioxide and water with enough ozone. But this dosage was much higher than the necessary ozone dosage for aniline's transformation, and there were still some intermediates that could not react with ozone.

In this experiment, there was only aniline in water. If there were other organic compounds coexisting in water, the increase of ozone dosage would increase the production of intermediates. Consequently, it is not economical to COD removal with ozonation alone [24]. The main purpose of ozonation should be to transform the complicated compounds into easily biodegradable intermediates. 


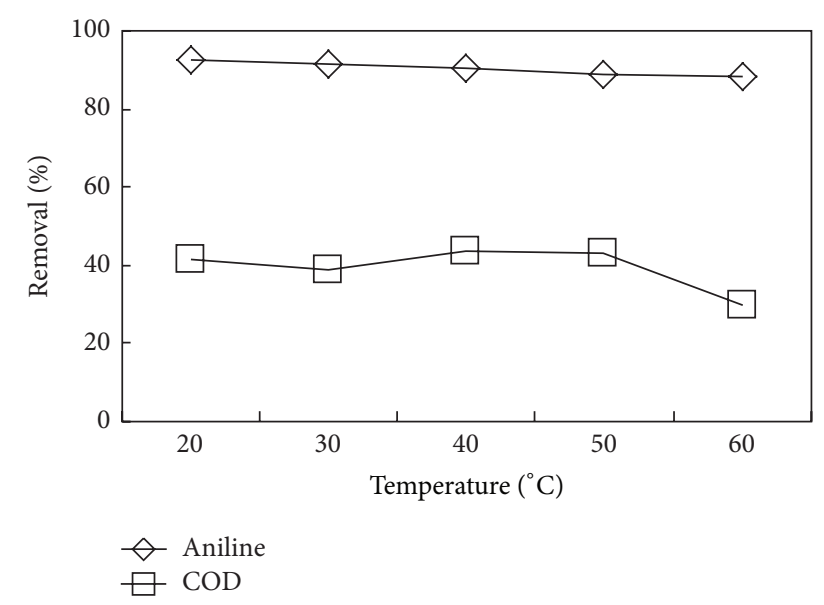

FIgURE 4: Effect of temperature on aniline and COD removal. $\mathrm{pH}$ : 7.0; ozone dosage: $22 \mathrm{mg} / \mathrm{L}$; initial aniline concentration: $100 \mathrm{mg} / \mathrm{L}$; contact time: $120 \mathrm{~min}$.

3.4. The Effect of Temperature on Aniline Ozonation. The effect of temperature on aniline's ozonation was studied with the temperature changed in the range of $20^{\circ} \mathrm{C}-60^{\circ} \mathrm{C}$ (Figure 4). It can be seen that the effect of temperature variation was minor on aniline's ozonation. With the temperature rising from $20^{\circ} \mathrm{C}$ to $60^{\circ} \mathrm{C}$, aniline removal only decreased from $92.83 \%$ to $88.26 \%$, while the corresponding COD removal decreased from $41.43 \%$ to $30.00 \%$. On one aspect, the temperature rise decreased the solubility of ozone in the water and accelerated the escape of ozone from the water [25], which affected the effect of aniline's degradation by ozonation. On another aspect, the temperature rise also speeded up the production of hydroxyl radicals with high oxidation capability [26]. The two effects above happened simultaneously and offset the influence of each other during temperature rise. Consequently, the temperature variation brought out slight effect on aniline's removal, and the ozonation of aniline could be operated at room temperature with high efficiency.

3.5. The Effect of $p H$ on Aniline Ozonation. With ozone dosage of $22 \mathrm{mg} / \mathrm{L}$ and temperature at $20^{\circ} \mathrm{C}$, the effect of $\mathrm{pH}$ on aniline ozonation was studied with $\mathrm{pH}$ variation in the range of 3-11 (Figure 5). With $\mathrm{pH}$ rise, the removal of aniline and COD increased obviously. Aniline removal increased from $58.61 \%$ at $\mathrm{pH} 3$ to $97.00 \%$ at $\mathrm{pH}$ 11, while COD removal increased from $31.43 \%$ to $80.00 \%$. At $\mathrm{pH} 7$, the ozonation removed $88.68 \%$ of aniline and $63.57 \%$ of COD. These data indicated aniline was susceptible to be degraded in alkaline conditions. This might be caused by the fact that ozone produced more hydroxyl radicals in alkaline conditions, which had a higher oxidation potential and could react more rapidly with most organic compounds compared with ozone molecules $[27,28]$. The hydroxyl radicals reacted with the intermediates during aniline ozonation, which accelerated both aniline removal and COD removal.

At different $\mathrm{pH}$ conditions, the ozonation of aniline showed many colors' variation. At alkaline conditions, there

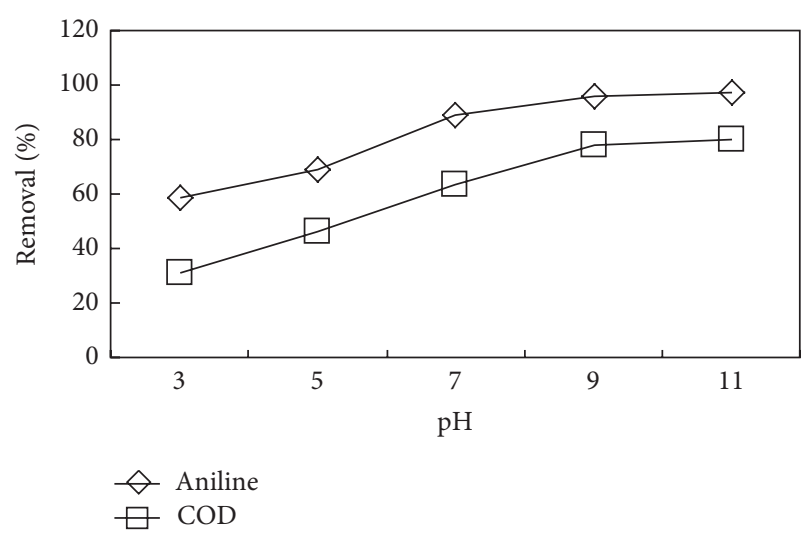

FIgURE 5: Effect of $\mathrm{pH}$ on aniline and COD removal. Temperature: $20^{\circ} \mathrm{C}$; $\mathrm{pH}$ : 7.0; ozone dosage: $22 \mathrm{mg} / \mathrm{L}$; initial aniline concentration: $100 \mathrm{mg} / \mathrm{L}$; contact time: $120 \mathrm{~min}$.

were drastic foams and offensive odor during aniline ozonation, which indicated the fast degradation of aniline and its intermediates during ozonation. At acid conditions, the colors variation, foams, and odor were not so obvious. At neutral $\mathrm{pH}$, the ozonation got satisfying performance in aniline removal compared with that at alkaline and acid conditions. This is significant for aniline's ozonation under neutral $\mathrm{pH}$ with simple operation and low cost.

3.6. The Analysis of Intermediates and Degradation Routes during Aniline's Ozonation. The GC-MS spectrum of aniline wastewater showed peak value at $4.95 \mathrm{~min}$ (Figure 6(a)). After two hours' ozonation, the removal of aniline was above $90 \%$. Figure 6(b) showed the peak value at $4.95 \mathrm{~min}$ decreased greatly and many other peak values appeared at $7.58 \mathrm{~min}, 11.57 \mathrm{~min}, 14.00 \mathrm{~min}$, and so on.

During ozonation, the aniline was gradually degraded into organic acids with low molecules such as butane diacid, oxalic acid, and formic acid [29]. The degradation of aniline during ozonation included tree processes: (1) the elementary phase: the main product was benzoquinone; (2) organic acids formation phase: the products of the elementary phase were further degraded into organic acids. At the beginning, the main product was butane diacid. After that, the concentration of oxalic acid increased, indicating the further degradation of organic compounds with long carbon chain; (3) the final degradation phase: the organic acids were degraded into the final products as carbon dioxide and water.

Except the compounds above, the azyl on the benzene ring was susceptible to being attacked by ozone and hydroxyl radicals. Consequently, there were many intermediates with imine groups which were mostly colored products [30].

\section{Conclusions}

With ozone dosage of $22 \mathrm{mg} / \mathrm{L}$, neutral $\mathrm{pH}$, and room temperature, the ozonation removed aniline efficiently. After two hours' ozonation, aniline removal reached $93.57 \%$, and the corresponding COD could not be removed completely. 


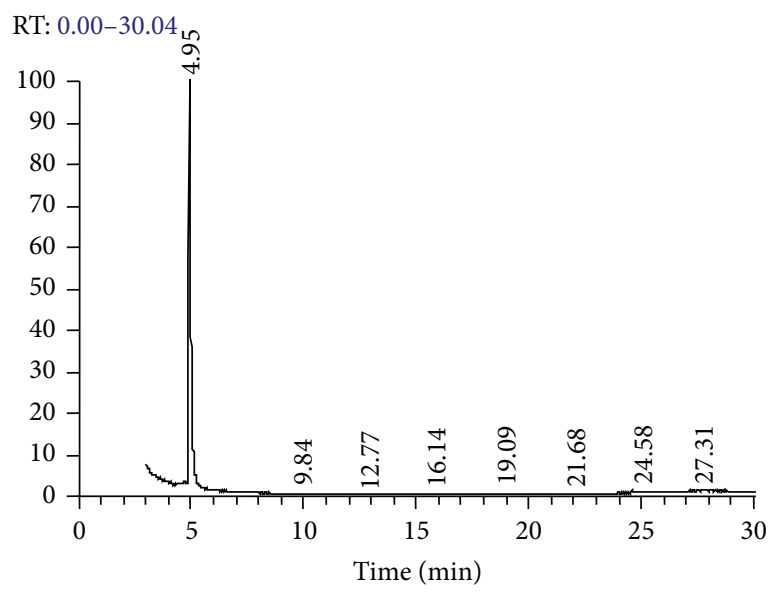

(a)

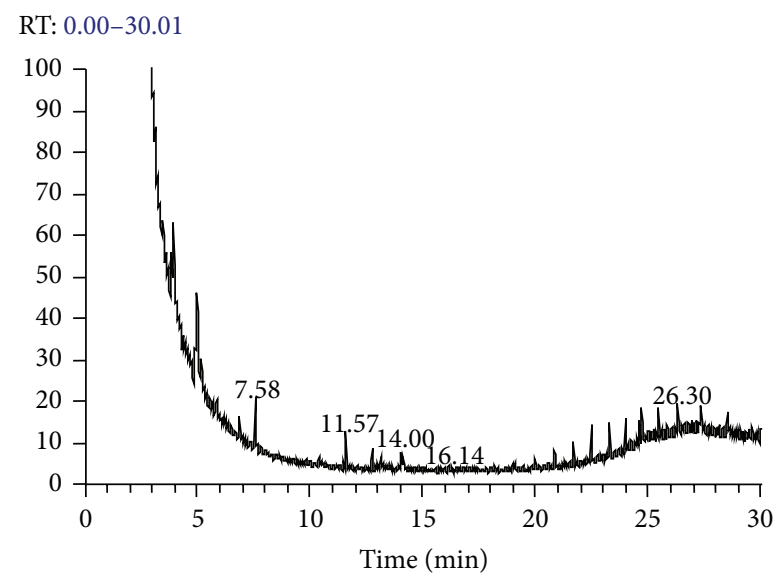

(b)

Figure 6: Spectrum of GC-MS of aniline wastewater before ozonation (a) and after ozonation (b).

After two hours' ozonation, the corresponding COD removal was only $31.03 \%$.

$\mathrm{pH}$ variation affected aniline removal obviously. At alkaline conditions, the aniline was more susceptible to being removed by ozonation owing to more hydroxyl radicals' production.

The results of GC-MS indicated many intermediates were produced during the process of ozonation such as butane diacid, oxalic acid, and formic acid. In the later phase, the proportion of organic compounds with low molecule increased. There were also many colored intermediates.

The intermediates produced during ozonation were more degradable than aniline; thus the ozonation of such organic compounds as aniline could be integrated with biological processes for further removal.

\section{Conflict of Interests}

The authors declare that there is no conflict of interests regarding the publication of this paper.

\section{Acknowledgments}

This research was supported by the National Science and Technology Support Program (2015BAL02B04), the Technology Project of China Housing and Urban-Rural Development Ministry (2015-K7-012), the Postgraduate Innovation Program of Jiangsu Province (SJLX15-0417), the Project of the Priority Academic Program Development of Jiangsu Higher Education Institutions (PAPD), and the Project Sponsored by the Scientific Research Foundation for the Returned Overseas Chinese Scholars, State Education Ministry.

\section{References}

[1] Q. Hu, D.-W. Gao, H. Pan, L. Hao, and P. Wang, "Equilibrium and kinetics of aniline adsorption onto crosslinked sawdustcyclodextrin polymers," RSC Advances, vol. 4, no. 75, pp. 4007140077, 2014.
[2] J. Sarasa, S. Cortés, P. Ormad, R. Gracia, and J. L. Ovelleiro, "Study of the aromatic by-products formed from ozonation of anilines in aqueous solution," Water Research, vol. 36, no. 12, pp. 3035-3044, 2002.

[3] G.-Q. Wu, X. Zhang, H. Hui et al., "Adsorptive removal of aniline from aqueous solution by oxygen plasma irradiated bamboo based activated carbon," Chemical Engineering Journal, vol. 185-186, pp. 201-210, 2012.

[4] G. Liu, Z. Wang, W. Zheng, S. Yang, and C. Sun, "Visible-lightdriven photocatalytic degradation of aniline over $\mathrm{NaBiO}_{3}$," Advances in Condensed Matter Physics, vol. 2014, Article ID 961609, 5 pages, 2014.

[5] N. Chen, L. Chen, Y. Cheng, K. Zhao, X. Wu, and Y. Xian, "Molecularly imprinted polymer grafted graphene for simultaneous electrochemical sensing of 4, 4-methylene diphenylamine and aniline by differential pulse voltammetry," Talanta, vol. 132, pp. 155-161, 2015.

[6] W. Wang and L. Zhang, "Hydrogen transfer hydrogenation of nitrobenzene to aniline with $\mathrm{Ru}(\mathrm{acac})_{3}$ as the catalyst," Research on Chemical Intermediates, vol. 40, no. 8, pp. 3109-3118, 2014.

[7] L. Zhu, M. Lv, X. Dai, X. Xu, H. Qi, and Y. Yu, "Reaction kinetics of the degradation of chloroanilines and aniline by aerobic granule," Biochemical Engineering Journal, vol. 68, pp. 215-220, 2012.

[8] L. W. Sun, M. M. Qu, Y. Q. Li et al., "Toxic effects of aminophenols on aquatic life using the zebrafish embryo test and the comet assay," Bulletin of Environmental Contamination and Toxicology, vol. 73, no. 4, pp. 628-634, 2004.

[9] M. Abdel Salam, M. A. Gabal, and A. Y. Obaid, "Preparation and characterization of magnetic multi-walled carbon nanotubes/ferrite nanocomposite and its application for the removal of aniline from aqueous solution," Synthetic Metals, vol. 161, no. 23-24, pp. 2651-2658, 2012.

[10] J. Garcia, H. T. Gomes, P. Serp, P. Kalck, J. L. Figueiredo, and J. L. Faria, "Carbon nanotube supported ruthenium catalysts for the treatment of high strength wastewater with aniline using wet air oxidation," Carbon, vol. 44, no. 12, pp. 2384-2391, 2006.

[11] J. M. Dias, M. C. M. Alvim-Ferraz, M. F. Almeida, J. RiveraUtrilla, and M. Sánchez-Polo, "Waste materials for activated carbon preparation and its use in aqueous-phase treatment: 
a review," Journal of Environmental Management, vol. 85, no. 4, pp. 833-846, 2007.

[12] G. Xiao and L. Long, "Efficient removal of aniline by a watercompatible microporous and mesoporous hyper-cross-linked resin and XAD-4 resin: a comparative study," Applied Surface Science, vol. 258, no. 17, pp. 6465-6471, 2012.

[13] Y.-P. Chang, C.-L. Ren, J.-C. Qu, and X.-G. Chen, "Preparation and characterization of $\mathrm{Fe}_{3} \mathrm{O}_{4}$ /graphene nanocomposite and investigation of its adsorption performance for aniline and $\mathrm{p}$ chloroaniline," Applied Surface Science, vol. 261, pp. 504-509, 2012.

[14] G. Zhao, X. Lu, and Y. Zhou, "Aniline degradation in aqueous solution by UV-aeration and UV-microO ${ }_{3}$ processes: efficiency, contribution of radicals and byproducts," Chemical Engineering Journal, vol. 229, pp. 436-443, 2013.

[15] M. Ferreira, M. Pinto, I. Neves et al., "Electrochemical oxidation of aniline at mono and bimetallic electrocatalysts supported on carbon nanotubes," Chemical Engineering Journal, vol. 260, pp. 309-315, 2015.

[16] T. D. Pham, R. A. Shrestha, J. Virkutyte, and M. Sillanpää, "Recent studies in environmental applications of ultrasound," Journal of Environmental Engineering and Science, vol. 8, no. 4, pp. 403-412, 2013.

[17] Y. Zhou, X. Gu, R. Zhang, and J. Lu, "Removal of aniline from aqueous solution using pine sawdust modified with citric acid and $\beta$-cyclodextrin," Industrial \& Engineering Chemistry Research, vol. 53, no. 2, pp. 887-894, 2014.

[18] S. Zhang, A. Li, D. Cui, J. Yang, and F. Ma, "Performance of enhanced biological SBR process for aniline treatment by mycelial pellet as biomass carrier," Bioresource Technology, vol. 102, no. 6, pp. 4360-4365, 2011.

[19] S. Hu, Y. Wu, L. Wang, H. Yao, and T. Li, "Simultaneous removal of nitrate and aniline from groundwater by cooperating heterotrophic denitrification with anaerobic ammonium oxidation," Desalination and Water Treatment, vol. 52, no. 40-42, pp. 7937-7950, 2014.

[20] T. Kayashima, H. Suzuki, T. Maeda, and H. I. Ogawa, "Realtime PCR for rapidly detecting aniline-degrading bacteria in activated sludge," Chemosphere, vol. 91, no. 9, pp. 1338-1343, 2013.

[21] APHA, Standard Methods for the Examination of Water and Wastewater, American Public Health Association, American Water Works Association and Water Environment Federation, Washington, DC, USA, 16th edition, 1995.

[22] P. C. C. Faria, J. J. M. Órfão, and M. F. R. Pereira, "Ozonation of aniline promoted by activated carbon," Chemosphere, vol. 67, no. 4, pp. 809-815, 2007.

[23] Q. Jin, Z. Hu, Z. Jin, L. Qiu, W. Zhong, and Z. Pan, "Biodegradation of aniline in an alkaline environment by a novel strain of the halophilic bacterium, Dietzia natronolimnaea JQ-AN," Bioresource Technology, vol. 117, pp. 148-154, 2012.

[24] Y.-C. Hsu, J.-H. Chen, and H.-C. Yang, "Calcium enhanced COD removal for the ozonation of phenol solution," Water Research, vol. 41, no. 1, pp. 71-78, 2007.

[25] E. Rischbieter, H. Stein, and A. Schumpe, "Ozone solubilities in water and aqueous salt solutions," Journal of Chemical \& Engineering Data, vol. 45, no. 2, pp. 338-340, 2000.

[26] M. S. Elovitz, U. von Gunten, and H.-P. Kaiser, "Hydroxyl radical/ozone ratios during ozonation processes. II. The effect of temperature, $\mathrm{pH}$, alkalinity, and DOM properties," Ozone: Science \& Engineering, vol. 22, no. 2, pp. 123-150, 2000.
[27] G. Kleiser and F. H. Frimmel, "Removal of precursors for disinfection by-products (DBPs) - differences between ozoneand OH-radical-induced oxidation," Science of the Total Environment, vol. 256, no. 1, pp. 1-9, 2000.

[28] M. F. Sevimli and H. Z. Sarikaya, "Ozone treatment of textile effluents and dyes: effect of applied ozone dose, $\mathrm{pH}$ and dye concentration," Journal of Chemical Technology and Biotechnology, vol. 77, no. 7, pp. 842-850, 2002.

[29] J. Feng, R. Liu, P. Chen et al., "Degradation of aqueous 3,4dichloroaniline by a novel dielectric barrier discharge plasma reactor," Environmental Science and Pollution Research, vol. 22, no. 6, pp. 4447-4459, 2015.

[30] N.-C. Shang and Y.-H. Yu, "Toxicity and color formation during ozonation of mono-substituted aromatic compounds," Environmental Technology, vol. 23, no. 1, pp. 43-52, 2002. 

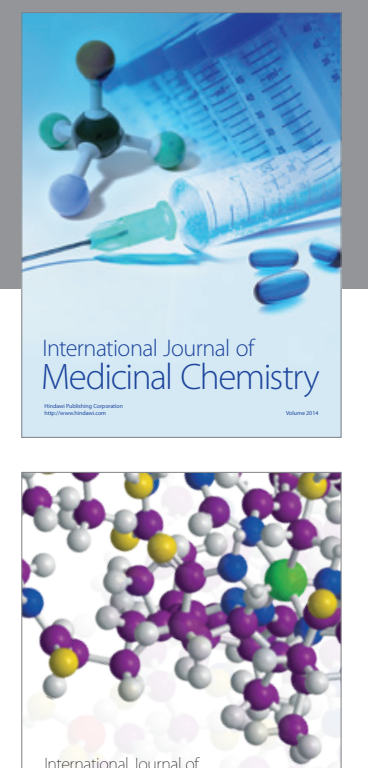

\section{Carbohydrate} Chemistry

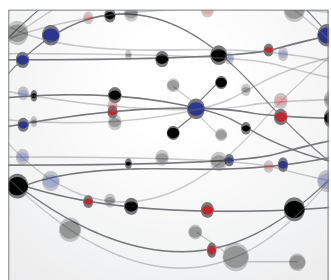

The Scientific World Journal
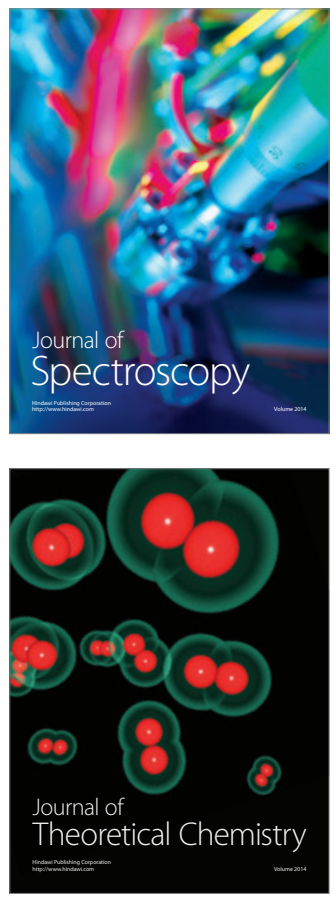
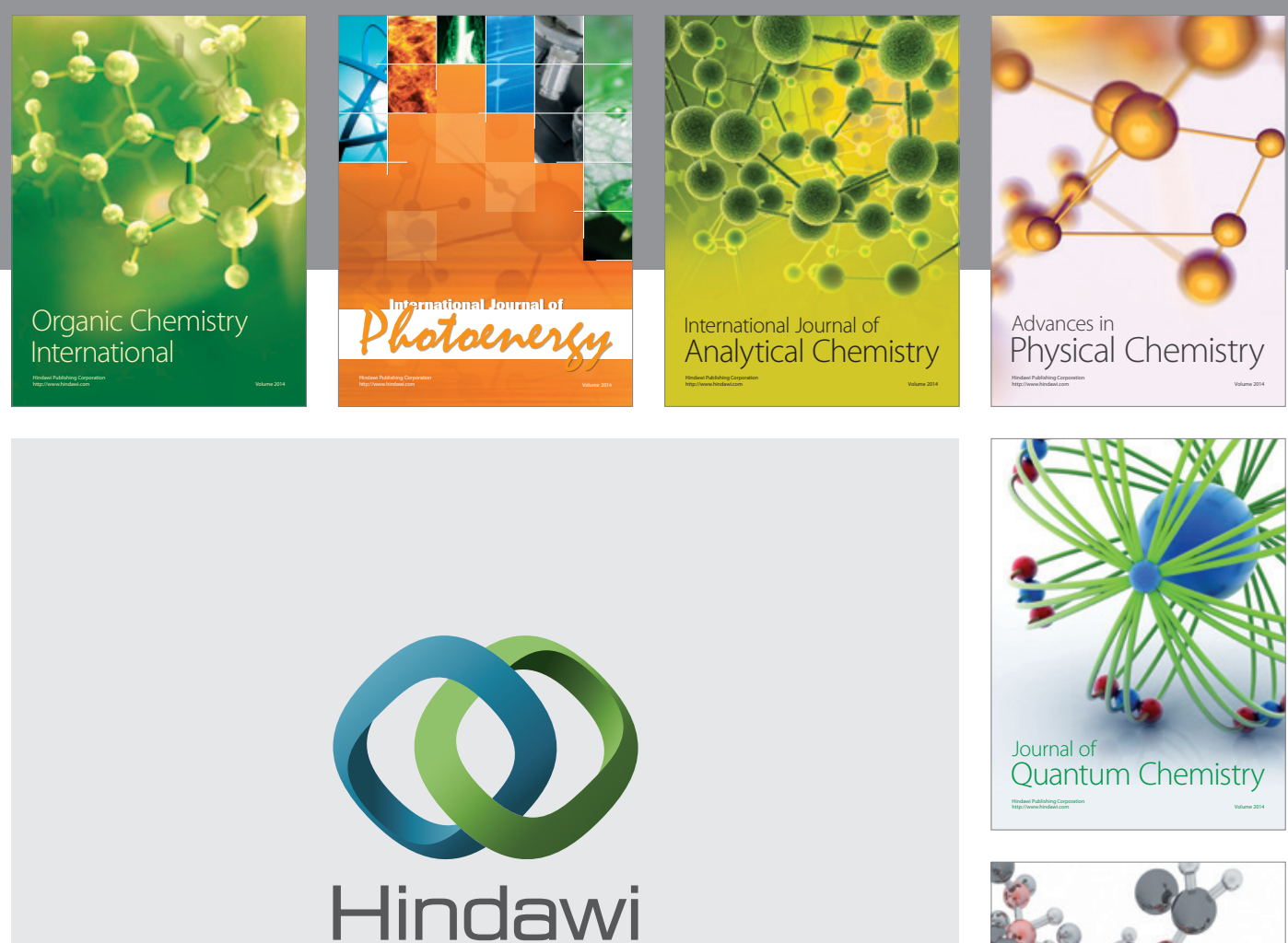

Submit your manuscripts at

http://www.hindawi.com

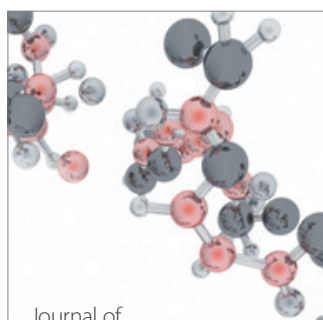

Analytical Methods

in Chemistry

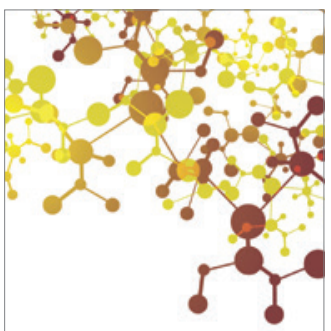

Journal of

Applied Chemistry

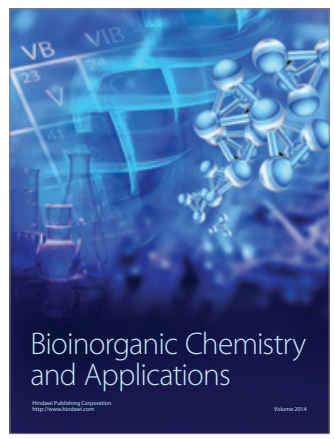

Inorganic Chemistry
